\title{
Milk metabolites as noninvasive indicators of nutritional status of mid-lactation Holstein and Montbéliarde cows
}

\author{
P. A. Billa, ${ }^{1} \odot$ Y. Faulconnier, ${ }^{1}$ T. Larsen, ${ }^{2} \odot$ C. Leroux, ${ }^{1} \oplus$ and J. A. A. Pires ${ }^{1 *}$ (๑) \\ ${ }^{1}$ INRAE, Université Clermont Auvergne, VetAgro Sup, UMR Herbivores, F-63122 Saint-Genès-Champanelle, France \\ ${ }^{2}$ Department of Animal Science, Aarhus University, DK-8830 Tjele, Denmark
}

\begin{abstract}
The objective was to investigate the effects of feed restriction on concentrations of selected milk metabolites in mid-lactation Holstein and Montbéliarde cows and to explore their correlations with energy balance and classic plasma and milk indicators of nutritional status. Eight Holstein and 10 Montbéliarde cows (165 $\pm 21 \mathrm{~d}$ in milk) underwent $6 \mathrm{~d}$ of feed restriction during which feed allowance was reduced to meet $50 \%$ of their net energy for lactation $\left(\mathrm{NE}_{\mathrm{L}}\right)$ requirements. The experiment was divided in 4 periods: control $(\mathrm{CON}$; $\mathrm{d}$ -3 to -1 ), restriction (RES; d 1 to 6 ), wk 1 (W1; d 7 to 13 ), and wk 2 (W2; d 14 to 18 ) after refeeding at ad libitum intake. Intake, milk production, energy balance and plasma metabolites were used to validate the feed restriction model. Concentrations of 7 milk metabolites: $\beta$-hydroxybutyrate (BHB), glucose, glucose6 -phosphate, isocitrate, glutamate, uric acid, and free amino groups were measured in morning milk samples, and fatty acids were measured in pooled p.m. and a.m. samples. Feed restriction induced a negative energy balance $(-42.5 \pm 4.4 \mathrm{MJ} / \mathrm{d})$, increased plasma nonesterified fatty acids and BHB, and decreased plasma glucose concentrations. Feed restriction increased milk glucose-6-phosphate and isocitrate $(+38 \%$ and $+39 \%$, respectively) and decreased milk BHB, glucose, glutamate, uric acid and free amino group concentrations $(-20 \%,-57 \%,-65 \%,-42 \%$, and $-14 \%$, respectively), compared with pre- restriction. Milk concentrations of medium-chain fatty acids (e.g., sum of C10 to C15) decreased and those of long chain (e.g., 18:0, cis-9 18:1) increased during restriction. Breed differences were not detected for the majority of variables. All studied milk metabolites were significantly correlated with energy balance (Spearman correlation $=0.48,0.63,-0.31$, -0.45 , and 0.61 for BHB, glucose, glucose-6-phosphate,
\end{abstract}

Received August 19, 2019.

Accepted December 11, 2019.

*Corresponding author: jose.pires@inrae.fr isocitrate, and glutamate, respectively). Milk glucose and glutamate showed the strongest correlations with plasma metabolites and milk FA associated with lipomobilization. These results suggest that milk metabolites may be used as noninvasive indicators of negative energy balance and metabolic status of dairy cows.

Key words: milk metabolites, lipomobilization, feed restriction, negative energy balance

\section{INTRODUCTION}

Milk composition is modulated by a diversity of factors, including genetics, lactation stage, and nutrition and health status; therefore, milk is an obvious source of biomarkers by which to monitor dairy ruminants. Early lactation is characterized by a rapid increase in milk yield, mobilization of body protein and fat reserves, negative energy balance (NEB), and modifications in milk protein, fat, and fatty acid (FA) composition. Complex homeorhetic and homeostatic adaptations are required to direct limiting nutrients toward the mammary gland and support milk synthesis during early lactation (Bell and Bauman, 1997). The occurrence of metabolic disorders related to energy metabolism is typical during this period, and plasma concentrations of nonesterified fatty acids (NEFA) and BHB are classic indicators for herd troubleshooting (Oetzel, 2004). Experimental feed restriction models are used to induce nutrient deficits and NEB at different stages of lactation and to assess the production and metabolic responses (Gross et al., 2011a; Bjerre-Harpøth et al., 2012; Friggens et al., 2016) and effects of NEB on various biological functions of the dairy cow (Moyes et al., 2009; Abdelatty et al., 2017; Pires et al., 2019). Metabolic responses to feed restriction models are greater during early lactation than in later stages (Bjerre-Harpøth et al., 2012) but it is more convenient to run experimental protocols during the mid-lactation period with less confounding due to the dynamic nature of early lactation (Contreras et al., 2016).

The reliance on body reserve mobilization for milk synthesis during early lactation is largely driven by ge- 
netics (Friggens et al., 2013). Breed differences between Holstein (HOLS) and Montbéliarde (MONT) cows have been described in various production systems (Dillon et al., 2003; Pomiès et al., 2007; Pires et al., 2015). Holstein cows prioritize milk, fat, protein, and lactose secretion compared with MONT (Dillon et al., 2003; Pomiès et al., 2007; Pires et al., 2015) but experience greater BCS loss and metabolic deviations during early lactation (Dillon et al., 2003; Pires et al., 2015). Therefore, we hypothesized that breed effects might be used as a model to induce different production and metabolic responses to a nutritional challenge.

Milk is a source of novel indicators of nutritional status of dairy cows. Milk sampling is easy to perform in dairy operations and can be automated for inline analyses. Certain molecules of intermediary metabolism are present in milk and may indicate physiological and nutritional status of dairy cows (Gross and Bruckmaier, 2019). For instance, milk is classically used to monitor ketosis by cow-side tests (Oetzel, 2004) and by automated inline BHB measurements. Milk glucose, glucose- 6 phosphate, and uric acid concentrations are modulated by diet digestibility and correlated with DMI in mid-lactation cows (Larsen et al., 2016). Furthermore, milk glucose and glucose- 6 phosphate concentrations vary with DIM (Larsen and Moyes, 2015; Zachut et al., 2016; Ferris et al., 2018).

Milk concentrations of these metabolites may reflect modifications of metabolic pathways in mammary epithelial cells, including glucose utilization for glycolysis and lactose synthesis (Chaiyabutr et al., 1981) and glucose-6-phosphate and isocitrate to produce reducing potential (i.e., NADPH) for de novo FA synthesis (Garnsworthy et al., 2006; Chaiyabutr et al., 1981) and to counterbalance oxidative stress associated with FA oxidation (Zachut et al., 2016). Milk uric acid originates in part from ruminal digestion of purine bases and has been suggested as an indicator of microbial protein synthesis (Larsen and Moyes, 2010). Milk glutamate and free AA content may reflect the availability and metabolism of amino acids.

The effects of NEB and breed on concentrations of minor milk metabolites are still insufficiently documented. We hypothesized that concentrations of selected metabolites in milk are modified during periods of NEB and may constitute novel indicators of energy balance and metabolic status of dairy cows. Thus, the objective was to determine the effects of NEB induced by partial feed restriction on milk concentrations of selected metabolites, assess potential differences between mid-lactation HOLS and MONT cows, and evaluate their relationships with classic indicators of metabolic status and lipomobilization.

\section{MATERIALS AND METHODS}

\section{Experimental Design, Animals, Diets, and Housing}

All procedures involving animals were approved by the Ethics Committee of the Auvergne-RhôneAlpes region and the French Ministry of Higher Education, Research and Innovation (APAFIS \# 3737-2015043014541577v2). Twenty multiparous midlactation cows $(165 \pm 21$ DIM), 10 Holstein-Friesian and 10 Montbéliarde $(1.5 \pm 0.29$ BCS, 0 to 5 scale $)$, were used to study the effects of $6 \mathrm{~d}$ of feed restriction to meet $50 \%$ of $\mathrm{NE}_{\mathrm{L}}$ requirements on milk production, classic plasma biomarkers, and putative milk biomarkers of metabolic status. Two HOLS cows were excluded from the study, one because of clinical mastitis and one due to noncompliance with the restriction protocol. Phenotypic measurements were performed from $\mathrm{d}-3$ to +18 relative to initiation of restriction, corresponding to the following periods: control $(\mathbf{C O N} ; \mathrm{d}-3$ to -1), restriction (RES; d 1 to 6 ), wk 1 (W1; d 7 to 13), and wk 2 (W2; d 14 to 18; Figure 1). Five cows of each breed were randomly allocated to a group of 10 animals that initiated the experimental protocol 1 d apart. Mammary and liver biopsies were performed on d 0 and d 6 for complementary studies (Billa et al., 2019). The experiment was conducted at the INRAE Herbipôle experimental farm Marcenat $\left(45^{\circ} 18^{\prime} 21^{\prime \prime} \mathrm{N}\right.$, $2^{\circ} 50^{\prime} 13^{\prime \prime} \mathrm{E} ; 1,100 \mathrm{~m}$ altitude; https://doi.org/10.15454/ 1.5572318050509348E12) during April and early May.

During CON, W1, and W2 periods, all cows were allowed ad libitum intake of a TMR (Table 1). During the RES period, feed allowance was reduced to meet $50 \%$ of individual $\mathrm{NE}_{\mathrm{L}}$ requirements calculated from BW, feed intake and milk production and composition recorded before restriction (INRA, 2007). Cows had free access to water and were housed in a freestall barn equipped with automatic feed bunks that control individual access and weight feed intake (CRFI, Biocontrol, Rakkestad, Norway). Gates were programmed to divide individual daily feed allowance in 4 equal portions in 6 -h periods. Cows ate $3 \pm 0.9 \mathrm{~kg}$ of hay $(58.9 \% \mathrm{NDF}$, $31.9 \% \mathrm{ADF}, 11.5 \% \mathrm{CP}$, and $5.4 \mathrm{MJ} / \mathrm{kg}$ of $\mathrm{DM}$ ) during the $2 \mathrm{~d}$ after refeeding to provide extra fiber and decrease the risk of ruminal acidosis due to the transition. The ration was analyzed for DM content to calculate individual DMI. Energy balance was estimated according to the INRA system (INRA, 2007), in which $\mathrm{NE}_{\mathrm{L}}$ is expressed in "unité fourragère lait" (UFL; 1 UFL = $7.12 \mathrm{MJ})$, as follows:

$$
\begin{gathered}
\text { Net energy }(\mathrm{NE}) \text { intake }(\mathrm{UFL})= \\
\mathrm{UFL} / \mathrm{kg} \mathrm{DM} \times \mathrm{DMI}(\mathrm{kg})-\mathrm{E},
\end{gathered}
$$




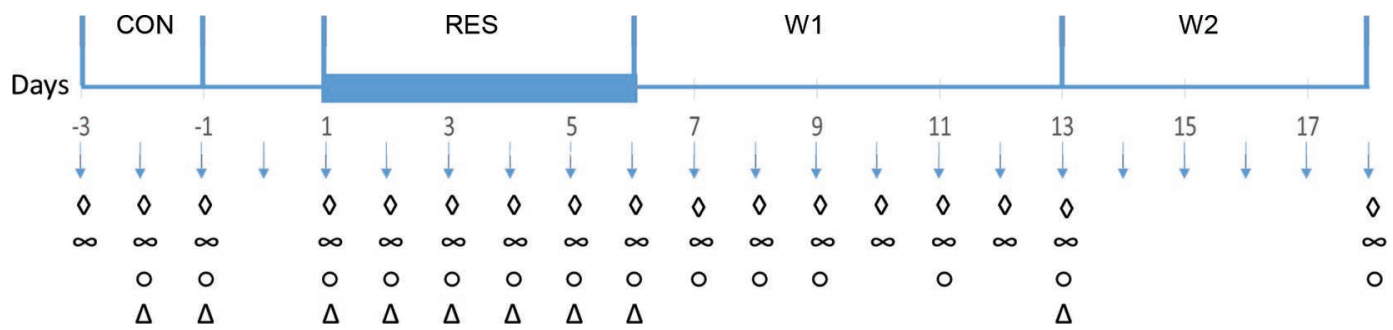

Figure 1. Sampling timeline. Control period (CON; d -3 to -1 ); restriction period (RES; $\mathrm{d} 1$ to 6 ), when feed intake was restricted to meet $50 \%$ of $\mathrm{NE}_{\mathrm{L}}$ requirements calculated during the CON period; wk 1 after refeeding (W1; d 7 to 13); wk 2 after refeeding (W2; d 14 to 18). $\diamond$ Milk yield and composition each milking; $\infty$ milk sampling for milk metabolite analyses ( 11 corresponds to samples collected at 24 h of feed restriction); $\bigcirc$ blood sampling for plasma metabolite and insulin analyses (d 1 corresponds to samples collected at $24 \mathrm{~h}$ of feed restriction); $\Delta$ milk sampling for milk fatty acid composition analyses (pooled p.m. and a.m. samples).

where E corresponds to the "digestive interaction," calculated as a function of the percentage concentrate in the diet (\% Conc; DM basis) and UFL intake [i.e., $\mathrm{UFL} / \mathrm{kg}$ of $\mathrm{DM} \times \mathrm{DMI}(\mathrm{kg})]$, using the formula

$$
\begin{gathered}
\mathrm{E}=\left(0.00063 \times \% \mathrm{Conc}^{2}\right)-(0.017 \times \mathrm{UFL} \text { intake }) \\
+\left(0.002 \times \mathrm{UFL}_{\text {intake }}^{2}\right)
\end{gathered}
$$

$$
\begin{gathered}
\text { NE production }(\mathrm{UFL})=\text { milk yield }(\mathrm{kg}) \\
\times\{0.44+[0.0055 \times(-40+\text { fat content; } \mathrm{g} / \mathrm{kg})] \\
+[0.0033 \times(-31+\text { protein content; } \mathrm{g} / \mathrm{kg})]\}
\end{gathered}
$$

$\mathrm{NE}$ maintenance $(\mathrm{UFL})=0.041 \times \mathrm{BW}^{0.75} \times 1.1$; and

Energy balance $(\mathrm{UFL})=$

NE intake - NE maintenance - NE production.

Table 1. Diet ingredient and nutrient composition (\% of DM unless otherwise noted)

\begin{tabular}{lr}
\hline Item & Value \\
\hline Ingredient & \\
Corn silage & 66.3 \\
Barley straw & 8.0 \\
Corn grain & 7.6 \\
Soybean meal & 17.4 \\
Mineral and vitamin mix 1 & 0.7 \\
Nutrient composition (DM basis) & \\
Net energy (MJ/kg of DM) & 6.9 \\
$\mathrm{PDI}^{2}(\mathrm{~g} / \mathrm{kg}$ of DM) & 106.0 \\
$\mathrm{CP}$ & 13.8 \\
Fat & 2.4 \\
Starch & 23.3 \\
NDF & 34.6 \\
ADF & 18.7 \\
\hline
\end{tabular}

${ }^{1}$ Mineral and vitamin contained $4.5 \% \mathrm{P}, 23 \% \mathrm{Ca}, 4.5 \% \mathrm{Mg}, 1 \% \mathrm{~S}$, $400,000 \mathrm{IU} / \mathrm{kg}$ vitamin $\mathrm{A}, 100,000 \mathrm{IU} / \mathrm{kg}$ vitamin $\mathrm{D}_{3}, 1,600 \mathrm{IU} / \mathrm{kg}$ vitamin E, $400 \mathrm{IU} / \mathrm{kg}$ vitamin $\mathrm{B}_{1}, 1 \mathrm{~g} / \mathrm{kg} \mathrm{Cu}, 5 \mathrm{~g} / \mathrm{kg} \mathrm{Zn}, 4 \mathrm{~g} / \mathrm{kg} \mathrm{Mn}, 0.1$ $\mathrm{g} / \mathrm{kg} \mathrm{I}, 40 \mathrm{mg} / \mathrm{kg} \mathrm{Co}$, and $24 \mathrm{mg} / \mathrm{kg}$ Se; Galaphos Midi Repro granule, CCPA, Aurillac, France.

${ }^{2} \mathrm{PDI}=$ true protein digestible in the small intestine (INRA, 2007).

\section{Sampling, Measurements, and Chemical Analyses}

Milk Sampling and Analysis. Cows were milked twice daily at approximately 0630 and $1600 \mathrm{~h}$. Milk yield was recorded and milk composition determined by mid-infrared spectroscopy (LIAL, Aurillac, France) in morning and evening milk samples. Weighted milk component means were computed according to p.m./ a.m. production and composition.

Morning milk samples were collected to determine metabolite concentrations on $\mathrm{d}-3,-2,-1,1,2,3,4$, $5,6,7,8,9,10,11,12,13$, and 18 relative to initiation of feed restriction (Figure 1), before distribution of fresh TMR, and conserved at $-20^{\circ} \mathrm{C}$ until analyses. Enzymatic-fluorometric methods were used to quantify milk content of BHB (Larsen and Nielsen, 2005), uric acid (Larsen and Moyes, 2010), isocitrate (Larsen, 2014), glucose and glucose-6-phosphate (Larsen, 2015), glutamate, and free amino groups $\left(\mathrm{NH}_{2}\right.$; Larsen and Fernández, 2017). Morning and evening milk samples were collected on $\mathrm{d}-2,-1,1,2,3,4,5,6$, and 13 to determine milk FA composition by GC, as previously described (Lerch et al., 2012). Briefly, samples were lyophilized and pooled according to p.m. and a.m. production, to provide daily composite samples for each cow. Samples were methylated and injected into 7890A GC system CN10271102 Series gas chromatograph equipped with a flame-ionization detector (Agilent Technologies, Santa Clara, CA). Peaks were routinely identified by comparison of retention times with FAME standards. Peak integration was conducted using Chemstation software (Agilent Technologies).

Blood Sampling and Analyses. Jugular blood samples were collected on d $-3,-2,1,2,3,4,5,6,7$, $8,9,11,13$, and 18 relative to initiation of feed restriction, after morning milking and before feed distribution. Blood samples were drawn into EDTA $(1.95 \mathrm{mg} /$ mL; Terumo Europe NV, Leuven, Belgium) and lithium heparin (135 U; Terumo Europe NV) tubes. Plasma was separated by centrifugation at $1,400 \times g$ for $15 \mathrm{~min}$ 
at $4^{\circ} \mathrm{C}$ and conserved at $-20^{\circ} \mathrm{C}$ until analysis. Plasma (EDTA) glucose, BHB, urea, and NEFA concentrations were quantified spectrophotometrically and insulin was measured by RIA (Pires et al., 2019). Plasma (heparin) glutamine, glutamate, and $\mathrm{NH}_{2}$ concentrations were quantified by enzymatic-fluorometric methods (Larsen and Fernández, 2017).

\section{Statistical Analyses}

Statistical analyses were performed using SAS software (version 9.4; SAS Institute Inc., Cary, NC). Daily data were analyzed as repeated measures by mixed models that included day, breed, and their interaction as fixed effects, cow as random effect, and KenwardRoger adjustment for calculation of degrees of freedom. Schwarz's Bayesian criterion was used to compare the fitting of different variance-covariance structures, including spatial power, first-order auto-regression $[\mathrm{AR}(1)]$, heterogeneous $\mathrm{AR}(1)$, and compound symmetry. The means for each variable within animal and period were calculated to compare periods (CON, RES, $\mathrm{W} 1$, and W2) and explore breed $\times$ period interactions. The models included the fixed effects of period, breed, and their interaction, and the random effect of cow. Significant time effects (i.e., day or period) and breed $\times$ time interactions were explored by Fisher's protected least significant difference using the PDIFF and SLICE options of the LSMEANS statement. Residuals were checked for normality and homoscedasticity. Heterogeneous variance was tested whenever suggested by residual plots. Least squares means (LSM) and standard error of the mean (SEM) were estimated from untrans- formed values, whereas $P$-values may reflect statistical analysis of log-transformed data when transformation was necessary. Relationships among variables were explored by Spearman rank correlations $\left(\mathbf{r}_{\mathrm{s}}\right)$. Linear regressions between energy balance and milk metabolite concentrations were analyzed using PROC REG procedure of SAS. The significance level was predefined as $P \leq 0.05$ and trends toward significance at $0.05<$ $P \leq 0.10$.

\section{RESULTS AND DISCUSSION}

\section{Production Responses}

Significant period effects were observed for DMI, energy balance, and milk and milk component yields (Table 2 and Supplemental Figure S1; https://doi.org/ 10.3168/jds.2019-17466). By design, energy balance became negative $(-42.5 \pm 4.4 \mathrm{MJ} / \mathrm{d})$ and milk, fat, and protein yields decreased during RES $(P<0.001)$. Energy balance returned to prerestriction values during W1, and DMI, fat, and protein yields returned to prerestriction values during W2. The effect of restriction on milk, fat, and protein yields are in accordance with previous studies in mid-lactation Holstein cows (Gross et al., 2011a; Bjerre-Harpøth et al., 2012; Pires et al., 2016).

A significant breed effect was observed for DMI and milk $(P=0.01)$, protein $(P=0.03)$, and lactose yields $(P=0.01)$, which were greater in HOLS than in MONT cows (Table 2). Energy balance and fat yield tended to be greater in HOLS than in MONT $(P=0.09$ and $P=0.07$, respectively). Nonetheless, milk yield

Table 2. Effects of feed restriction on energy balance, DMI, milk yield, and milk component yield in mid-lactation Holstein (HOLS) and Montbéliarde (MONT) cows ${ }^{1}$

\begin{tabular}{|c|c|c|c|c|c|c|c|c|c|}
\hline Item & Breed & \multicolumn{4}{|c|}{ Period } & SEM & \multicolumn{3}{|c|}{$P$-value } \\
\hline \multirow[t]{2}{*}{ Energy balance (MJ/d) } & HOLS & $37^{\mathrm{a}}$ & $-42^{\mathrm{b}}$ & $34^{\mathrm{a}}$ & $34^{\mathrm{a}}$ & 5 & 0.09 & $<0.001$ & 0.09 \\
\hline & MONT & 23 & -43 & 23 & 32 & 4 & & & \\
\hline \multirow[t]{2}{*}{ DMI (kg/d) } & HOLS & $25^{\mathrm{a}}$ & $9^{\mathrm{c}}$ & $22^{\mathrm{b}}$ & $24^{\mathrm{a}}$ & 0.8 & 0.01 & $<0.001$ & 0.08 \\
\hline & MONT & 21 & 8 & 19 & 23 & 0.8 & & & \\
\hline Milk yield $(\mathrm{kg} / \mathrm{d})$ & HOLS & $29^{\mathrm{a}}$ & $19^{\mathrm{d}}$ & $24^{\mathrm{c}}$ & $27^{\mathrm{b}}$ & 1.2 & 0.01 & $<0.001$ & 0.25 \\
\hline Fat yield $(\mathrm{g} / \mathrm{d})$ & MONT & 896 & 695 & 739 & 919 & 38 & & & \\
\hline \multirow[t]{2}{*}{ Protein yield $(\mathrm{g} / \mathrm{d})$} & HOLS & $883^{\mathrm{a}}$ & $565^{\mathrm{c}}$ & $722^{\mathrm{b}}$ & $844^{\mathrm{a}}$ & 38 & 0.03 & $<0.001$ & 0.75 \\
\hline & MONT & 785 & 494 & 628 & 782 & 36 & & & \\
\hline \multirow{2}{*}{ Lactose yield $(\mathrm{g} / \mathrm{d})$} & HOLS & $1,466^{\mathrm{a}}$ & $966^{\mathrm{d}}$ & $1,197^{\mathrm{c}}$ & $1,316^{\mathrm{b}}$ & 68 & 0.01 & $<0.001$ & 0.28 \\
\hline & MONT & 1,217 & 797 & 1,007 & 1,180 & 63 & & & \\
\hline \multirow{2}{*}{ BW (kg) } & HOLS & $680^{\mathrm{a}}$ & $628^{\mathrm{c}}$ & - & $661^{\mathrm{b}}$ & 21 & 0.35 & $<0.001$ & 0.64 \\
\hline & MONT & 661 & 605 & - & 626 & 19 & & & \\
\hline
\end{tabular}

\footnotetext{
${ }^{\mathrm{a}-\mathrm{d}}$ Period means (main period effects pooled across both breeds) not sharing a common superscript differ $(P \leq 0.05)$.

${ }^{1}$ Intake was limited to meet $50 \%$ of $\mathrm{NE}_{\mathrm{L}}$ requirements during restriction period (RES, d 1 to 6 ). Cows were allowed ad libitum intake during the control period (CON, d -3 to -1 ) and after restriction (W1, d 7 to 13; W2, d 14 to 18).
} 
differences between HOLS and MONT during CON $(+17 \%$ for HOLS $)$ were less marked than reported in previous studies during mid-lactation $(+21 \%$; Pomiès et al., 2007; Ferlay et al., 2010). Differences among studies could be explained by feeding systems, milking frequency, or lactation stage.

\section{Plasma Metabolite and Insulin Concentrations}

Plasma metabolite and insulin concentrations are presented in Table 3 and Supplemental Figures S2 and S3 (https://doi.org/10.3168/jds.2019-17466). Significant time effects were observed for all plasma variables. Plasma NEFA, BHB, and glutamate increased, whereas plasma glucose, glutamine, urea, $\mathrm{NH}_{2}$, and insulin concentrations decreased during RES $(P<0.01)$. Plasma NEFA, BHB, glucose, and $\mathrm{NH}_{2}$ returned to $\mathrm{CON}$ values in W1. Plasma glutamine, urea, and $\mathrm{NH}_{2}$ returned to $\mathrm{CON}$ values in W2. Plasma glutamate was significantly lower at the end of W2 than before the challenge. Plasma glucose concentrations returned to CON during $\mathrm{W} 1$ and became greater than $\mathrm{CON}$ concentrations on W2. Plasma insulin was significantly greater than CON concentrations on W1 but lower than CON on W2.

The increase in plasma NEFA concentrations during RES reflects lipomobilization (Chilliard et al., 2000a) and is in accordance with previous feed-restriction studies involving mid- and late-lactation cows (BjerreHarpøth et al., 2012; Gross et al., 2011a; Pires et al.,
2016). Nonetheless, the increase in plasma NEFA observed during RES in our experiment was smaller than that observed in underfed early lactation cows (BjerreHarpøth et al., 2012; Pires et al., 2019). Plasma BHB concentrations increased during restriction (Table 3 and Supplemental Figure S2), but remained below the $1.2 \mathrm{~m} M$ threshold of subclinical ketosis (LeBlanc et al., 2005 ), which is in agreement with previous research in underfed mid-lactation cows (Moyes et al., 2009; Gross et al., 2011a; Bjerre-Harpøth et al., 2012). As plasma BHB originates in part from rumen butyrate (Miettinen and Huhtanen, 1996), its concentrations observed during RES probably reflect concomitant modifications of DMI and ruminal butyrate synthesis and incomplete $\beta$-oxidation of mobilized NEFA. Two cows had increased concentrations of BHB the morning after refeeding the TMR at ad libitum intake (d 7; Supplemental Figure S3), which may result from increased DMI and a shift in ruminal butyrate production. Accordingly, insulin was greatest the day after refeeding at ad libitum intake (d 7, Supplemental Figure S2).

The decrease in plasma concentrations of glutamine and $\mathrm{NH}_{2}$ observed during RES may reflect reduced DMI and AA absorption. Glutamine and glutamate are intermediates in many anabolic and catabolic pathways, including regulation of metabolic acidosis, lymphocyte proliferation, and casein synthesis (Lobley et al., 2001). Plasma glutamine, glutamate, and total AA concentrations decrease during periods of NEB, such as early

Table 3. Effects of feed restriction on plasma metabolite and insulin concentrations in mid-lactation Holstein (HOLS) and Montbéliarde $(\mathrm{MONT}) \operatorname{cows}^{1}$

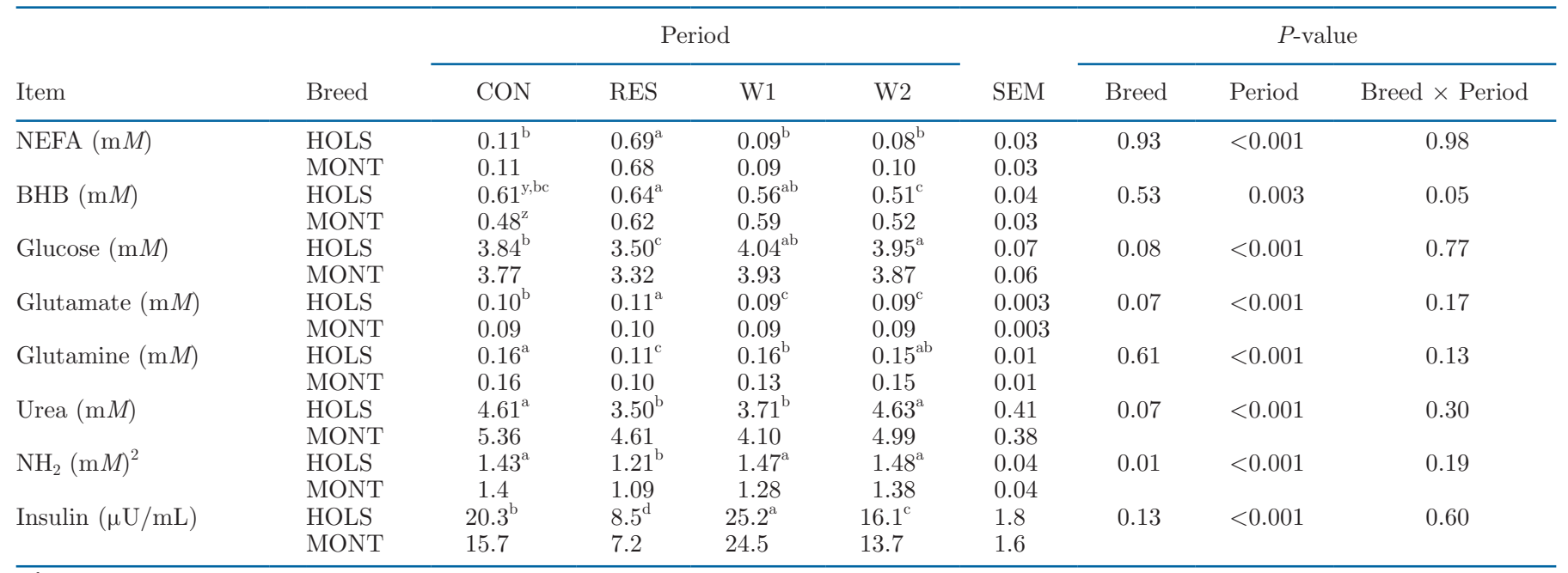

\footnotetext{
${ }^{\mathrm{a}-\mathrm{d}}$ Period means (main period effects pooled across both breeds) not sharing a common superscript differ $(P \leq 0.05)$.

${ }^{\mathrm{y}, \mathrm{z}}$ Breed means not sharing a common superscript differ within the period $(P \leq 0.05$; presented when Breed $\times$ Period effect was significant).

${ }^{1}$ Intake was limited to meet $50 \%$ of $\mathrm{NE}_{\mathrm{L}}$ requirements during restriction period (RES, d 1 to 6 ). Cows were allowed ad libitum intake during control period (CON, d -3 to -1 ) and after restriction (W1, d 7 to 13; W2, d 14 to 18).

${ }^{2}$ Free amino groups $\left(\mathrm{NH}_{2}\right)$ : estimation of free AA concentration.
} 
Table 4. Effects of feed restriction on milk metabolite concentrations in mid-lactation Holstein (HOLS) and Montbéliarde (MONT) cows ${ }^{1}$

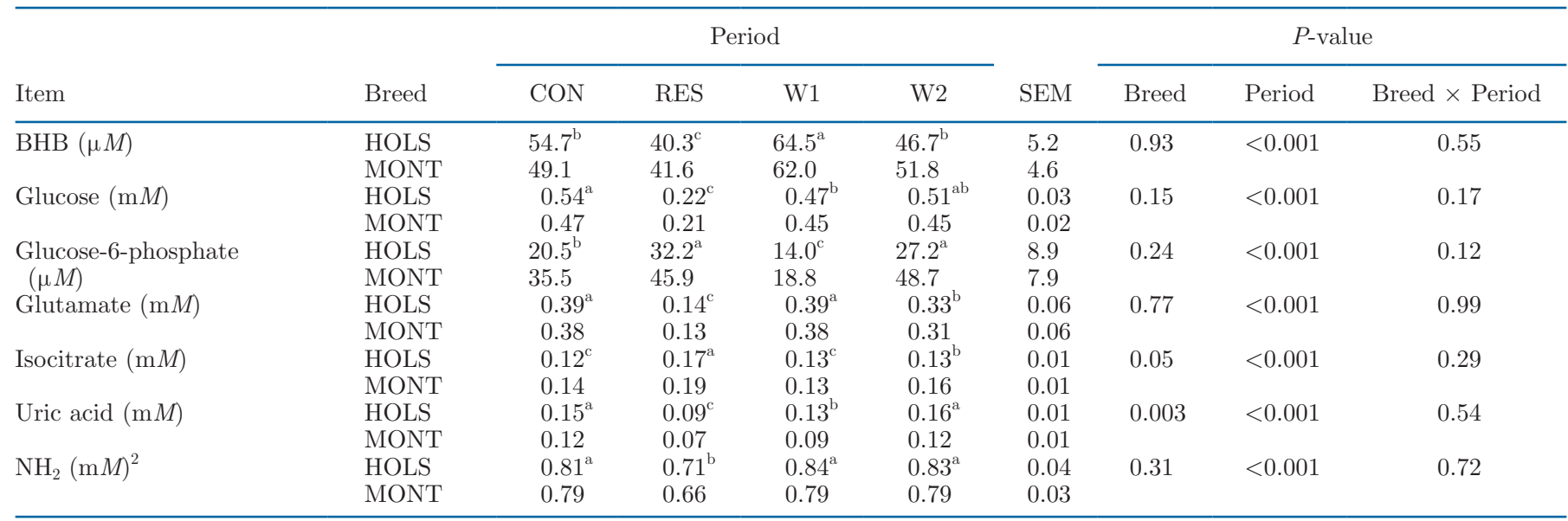

${ }^{\mathrm{a}-\mathrm{c}}$ Period means (main period effects pooled across both breeds) not sharing a common superscript differ $(P \leq 0.05)$.

${ }^{1}$ Intake was limited to meet $50 \%$ of $\mathrm{NE}_{\mathrm{L}}$ requirements during restriction period (RES, d 1 to 6 ). Cows were allowed ad libitum intake during the control period (CON, d -3 to -1 ) and after restriction (W1, d 7 to 13; W2, d 14 to 18).

${ }^{2}$ Free amino groups $\left(\mathrm{NH}_{2}\right)$ : estimation of free AA concentration (Larsen and Fernández, 2017).

lactation (Meijer et al., 1995), and during experimental feed restriction in mid-lactation cows (Girard et al., 2019). A decreased supply of AA for intestine absorption may have contributed more to these changes than AA catabolism, because plasma urea concentration also decreased during RES, as previously suggested (Girard et al., 2019). The increase in plasma glutamate concentration observed during RES (Table 3 and Supplemental Figure S3) may be due in part to spontaneous deamination of glutamine.

Holstein cows had greater plasma glucose, glutamate, and $\mathrm{NH}_{2}$ concentrations than MONT (Supplemental Figures S2 and S3). The greater glucose concentrations observed in HOLS than in MONT contrast with previous research during the first weeks of lactation in lowinput systems (Pires et al., 2015). These discrepancies may be explained by different lactation stages (early vs. mid-lactation), diet, and undernutrition model (earlylactation spontaneous NEB vs. mid-lactation feed restriction). The greater BHB concentrations observed in HOLS during CON (Table 3) probably reflect their greater DMI, ruminal butyrate, and BHB synthesis compared with MONT, because all animals were in positive energy balance.

\section{Milk Metabolite Concentrations}

Significant time effects were observed for milk concentrations of all metabolites studied (Table 4, Figures 2 and 3). Milk BHB, glucose, glutamate, uric acid, and $\mathrm{NH}_{2}$ decreased, whereas glucose-6-phosphate and isocitrate concentrations increased during $\operatorname{RES}(P<$ 0.001). Milk glutamate, isocitrate, and $\mathrm{NH}_{2}$ concentra- tions returned to prerestriction values in W1. Milk $\mathrm{BHB}$, glucose, and uric acid returned to prerestriction concentrations in W2. Milk glutamate was significantly greater and glucose-6-phosphate and isocitrate concentrations were significantly lower in $\mathrm{W} 2$ than in $\mathrm{CON}$.

The decrease in milk uric acid concentrations observed during RES is in agreement with results obtained when cows were offered low energy diets (Larsen et al., 2016). Milk BHB concentrations decreased during RES despite a small but significant increase in plasma BHB, which suggests that BHB was preferentially metabolized in the mammary gland. In contrast, BHB concentrations increased in both plasma and milk during early lactation, and both matrices are used to diagnose subclinical ketosis (Nielsen et al., 2003; Oetzel, 2004). Increased milk glucose-6-phosphate and isocitrate and decreased milk glucose concentrations during RES are in agreement with previous observations in starved goats (Chaiyabutr et al., 1981) and in early-lactation cows (Larsen and Moyes, 2015; Zachut et al., 2016). Glucose-6-phosphate and isocitrate are precursors for NADPH synthesis via the pentose phosphate and isocitrate dehydrogenase pathways, respectively. Increased milk glucose-6-phosphate and isocitrate content during RES may reflect a shift in these pathways in mammary epithelial cells, due to low plasma insulin, decreased de novo FA synthesis, and synthesis of other milk components.

Significant breed effects were observed for milk uric acid and isocitrate concentrations when individual data were analyzed by period (Table 4). Nonetheless, only a trend was detected for milk isocitrate concentration when daily data were analyzed as repeated measures, 
probably because many time points measured after refeeding (W1 and W2) did not differ between HOLS and MONT (Figures 2 and 3 ). Breed $\times$ time interactions were not observed for any of the milk metabolites analyzed in this study.

\section{Milk Fatty Acid Concentrations}

Milk FA concentrations are presented in Table 5 and Supplemental Figure S4 (https://doi.org/10.3168/jds .2019-17466). Significant time effects were observed for
A

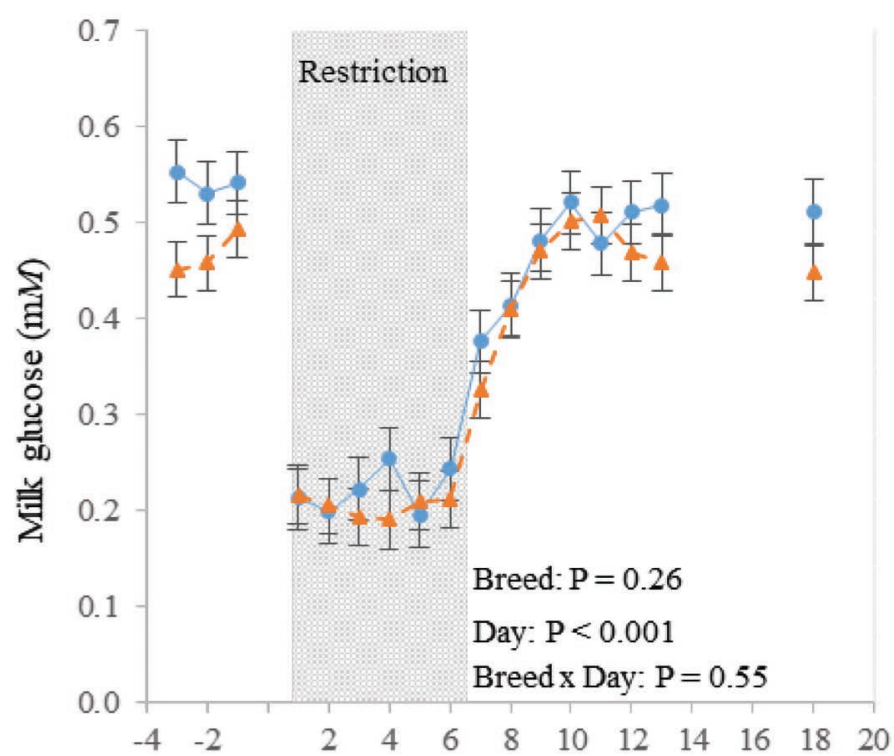

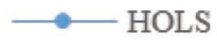

$--\perp-$ MONT

B

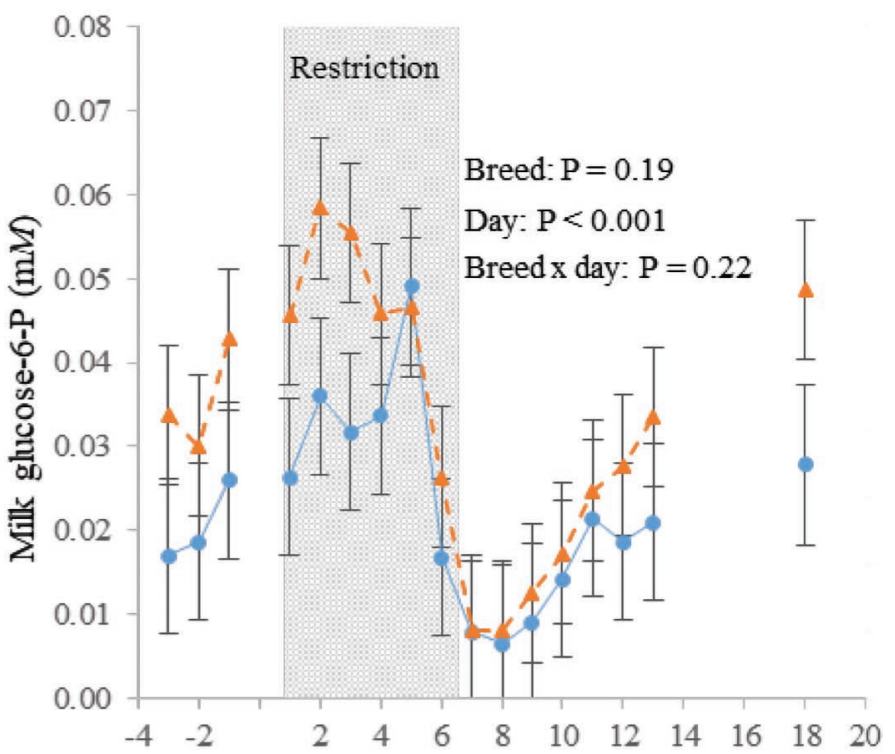

C

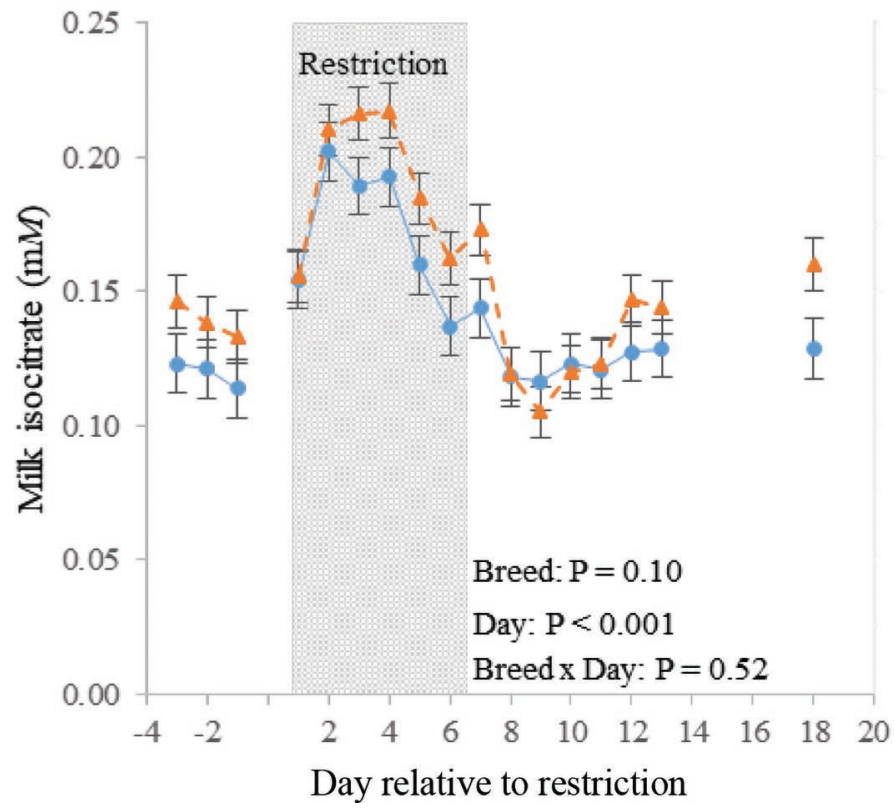

D

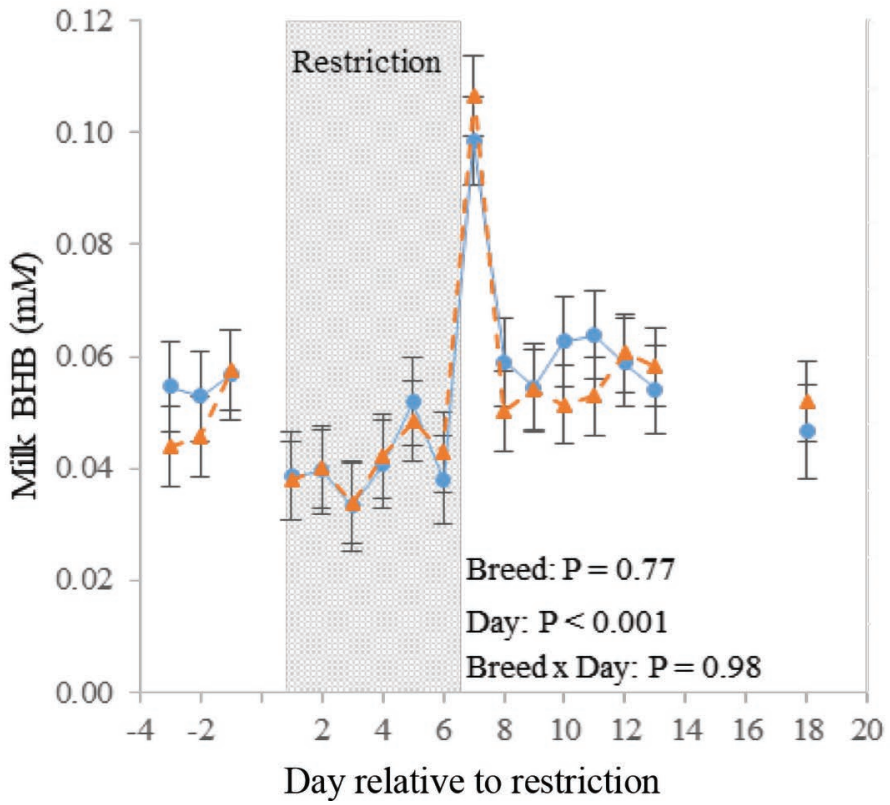

Figure 2. Effects of feed restriction on milk concentrations of (A) glucose, (B) glucose-6-phosphate, (C) isocitrate, and (D) BHB in midlactation Holstein (HOLS; $\bullet$, solid lines) and Montbéliarde (MONT; $\boldsymbol{\Lambda}$, dashed lines) cows. Intake was limited to meet $50 \%$ of $\mathrm{NE}_{\mathrm{L}}$ requirements during restriction period ( $\mathrm{d} 1$ to 6 ). Cows were allowed ad libitum intake during control period ( $\mathrm{d}-3$ to -1 ) and after restriction (d 7 to 18 ). Values are $\mathrm{LSM} \pm \mathrm{SEM}$. 


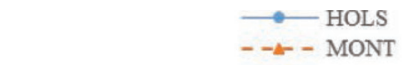

A

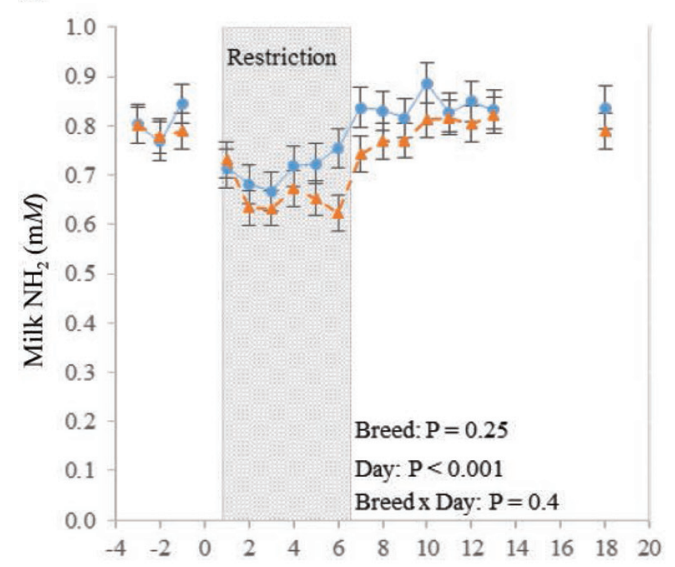

B

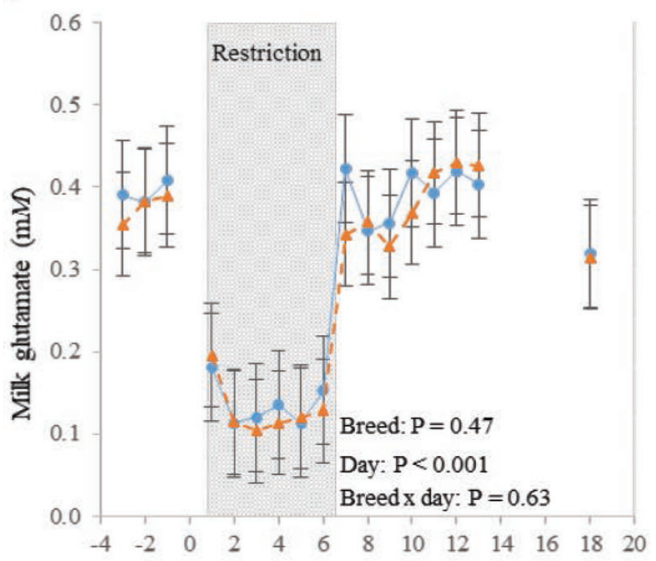

C

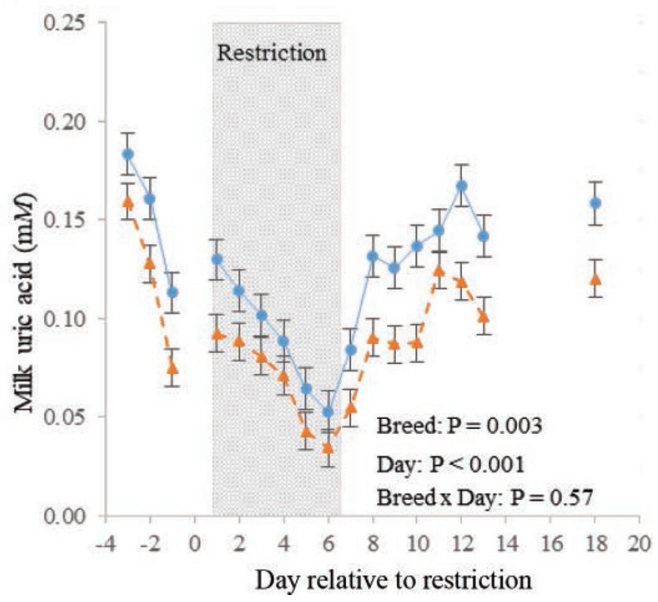

Figure 3. Effects of feed restriction on milk concentrations of (A) free amino groups $\left(\mathrm{NH}_{2}\right)$, (B) glutamate, and (C) uric acid in midlactation Holstein (HOLS; $\bullet$, solid lines) and Montbéliarde (MONT; $\boldsymbol{\Lambda}$, dashed lines) cows. Intake was limited to meet $50 \%$ of $\mathrm{NE}_{\mathrm{L}}$ requirements during restriction period (d 1 to 6 ). Cows were allowed ad libitum intake during control period ( $\mathrm{d}-3$ to -1$)$ and after restriction $(\mathrm{d}$ 7 to 18$)$. Values are LSM \pm SEM. all FA and FA classes $(P<0.001)$, except for total odd- and branched-chain FA ( $\boldsymbol{\Sigma}$ OBCFA). Milk FA concentrations returned to prechallenge values on d 13 , except for OBCFA.

Concentrations of FA with 10 to 15 carbons $(\Sigma 10: 0$ to $15: 0), 16: 0$, and $\Sigma$ OBCFA with carbon chain $<16$ ( $\Sigma$ OBCFA $<$ C16) decreased during RES, whereas concentration of 18:0 and cis-9 18:1 and of FA with carbon chain $>16(\Sigma>$ C16) increased. These modifications in milk FA profile are in agreement with other feed restriction studies (Chilliard et al., 2000b; Gross et al., 2011b; Abdelatty et al., 2017). The decreases in $\Sigma 10: 0$ to 15:0 and 16:0 during RES reflect a diminution of de novo FA synthesis in mammary gland due to decreased availability of precursors (e.g., acetate and propionate) absorbed from rumen (Chilliard et al., 2000b; Gross et al., 2011b). The increase in 18:0, cis-9 18:1, and $\Sigma$ $>$ C16 FA reflect body fat mobilization (Chilliard et al., 2000b; Gross et al., 2011b; Pires et al., 2013).

Concentrations of $\Sigma 10: 0$ to 15:0 and 16:0 decreased until d 3 of RES (Supplemental Figure S4; https:// doi.org/10.3168/jds.2019-17466), indicating a gradual downregulation of de novo FA synthesis. This downregulation would reduce NADPH requirements for mammary gland lipogenesis (Bell and Bauman, 1997) and might explain the gradual increase in glucose6-phosphate and isocitrate concentrations during RES, which became significant at $48 \mathrm{~h}$ of RES (Figure 2). This pattern may reflect concomitant effects of limiting plasma glucose availability and reduced glucose uptake by mammary gland during RES, downregulation of lactose synthesis (Chaiyabutr et al., 1981), and decreased NADPH requirements for de novo FA synthesis (Chaiyabutr et al., 1981; Garnsworthy et al., 2006). Milk glucose-6-phosphate and isocitrate concentrations decreased on d 5 and 6 of RES, before refeeding at ad libitum intake. Epithelial cell homeostatic mechanisms may have reestablished an equilibrium between cytosolic concentrations of glucose 6-phosphate and isocitrate and the activity of metabolic pathways for which they are precursors (e.g., NADPH and lactose synthesis). Zachut et al. (2016) proposed that FA oxidation in mammary cells during periods of lipomobilization would increase oxidative stress, requiring upregulation of the pentose phosphate pathway to generate reducing potential to neutralize reactive oxygen species. Mammary gland gene expression shows a shift toward increased reliance on $\beta$-oxidation for energy and sparing of glucose in underfed early-lactation cows (Pawłowski et al., 2019). Oxidative stress may have occurred in our study, inducing a gradual depletion of glucose6 -phosphate and isocitrate on d 5 and 6 of restriction. Indicators of oxidative stress were not measured in the current study. 
The decrease in $\Sigma$ OBCFA $<$ C16 observed during restriction (Table 5 and Supplemental Figure S4) may be explained by reduced ruminal synthesis and incorporation of absorbed FA into milk fat. The increase in milk $\Sigma$ OBCFA >C16 content (data not shown) during RES suggests that these FA were mobilized from adipose tissue. The majority of milk OBCFA originates from digested rumen bacteria. Branched-chain FA are synthesized by elongation of carbon chains originating from branched-chain AA (e.g., valine, leucine, and isoleucine), and part of the odd-chain FA are synthesized by elongation of propionate and valerate. A smaller proportion is synthesized de novo from elongation of propionate (Vlaeminck et al., 2005, 2015).

A breed effect was observed for milk 18:0 content, which was greater in HOLS than in MONT cows. No breed $\times$ time interaction was observed for milk FA concentrations.

\section{Correlation and Regression Analyses}

Correlations are presented in Tables 6 and 7 and regressions between energy balance and milk metabolites are presented in Figure 4 and Supplemental Figure S5 (https://doi.org/10.3168/jds.2019-17466). All variables presented were significantly correlated with energy balance, except plasma urea concentration and milk total OBCFA content. Among plasma metabolites, NEFA and glucose had the greatest absolute correlation with energy balance $\left(\mathrm{r}_{\mathrm{s}}=-0.72\right.$ and $\mathrm{r}_{\mathrm{s}}=0.64$, respectively; Table 6). Among milk metabolites, milk glucose and glutamate had the greatest absolute correlations with energy balance $\left(\mathrm{r}_{\mathrm{s}}>0.60\right)$ and plasma NEFA $\left(\mathrm{r}_{\mathrm{s}}=\right.$ -0.67 ; Table 6 ), which is a classic indicator of lipomobilization. Moreover, milk glucose was correlated with plasma glucose $\left(\mathrm{r}_{\mathrm{s}}=0.61\right)$ which is also modulated by NEB (Gross et al., 2011a; Bjerre-Harpoth et al., 2012; Pires et al., 2016). Milk isocitrate and glucose-6-phosphate concentrations were negatively correlated with energy balance $\left(\mathrm{r}_{\mathrm{s}}=-0.45\right.$ and -0.31 , respectively; Table 6). Milk glucose and milk glutamate concentrations presented the best regressions with energy balance $\left(\mathrm{R}^{2}=0.49\right.$ and 0.46 , respectively; $P<0.001$; Figure 4$)$, whereas milk glucose-6-phosphate and milk isocitrate presented a weak regression with energy balance $\left(\mathrm{R}^{2}=\right.$ 0.10 and 0.26 , respectively; $P<0.001$ ). These results suggest that milk glucose and glutamate concentrations may be good indicators of NEB and metabolic status of dairy cows.

Table 7 presents milk FA correlations with selected variables. Milk FA composition was used as a biomarker of lipomobilization in this study, and was measured in pooled samples of p.m./a.m. milkings; therefore, it integrates modifications occurring during 24-h periods, as for the calculations of energy balance. Milk $\Sigma>$ C16, 18:0, and cis-9 18:1 were negatively correlated with energy balance $\left(\mathrm{r}_{\mathrm{s}}=-0.54\right.$ to -0.56$)$, whereas milk $\Sigma 10: 0$ to $15: 0,16: 0$, and $\Sigma$ OBCFA $<$ C16 were positively correlated with energy balance $\left(\mathrm{r}_{\mathrm{s}}=\right.$ 0.39 to 0.52 ). These results were expected because of the known associations among NEB, lipomobilization, and milk FA composition (Gross et al., 2011b; Pires

Table 5. Effects of feed restriction on milk fatty acid (FA) concentrations ( $\mathrm{g} / 100 \mathrm{~g}$ of FA; composition measured in pooled p.m. and a.m. samples) in mid-lactation Holstein (HOLS) and Montbéliarde (MONT) cows ${ }^{1}$

\begin{tabular}{|c|c|c|c|c|c|c|c|c|}
\hline Item & Breed & \multicolumn{3}{|c|}{ Period } & SEM & \multicolumn{3}{|c|}{$P$-value } \\
\hline \multirow[t]{2}{*}{$\overline{\Sigma 10: 0 \text { to } 15: 0^{2}}$} & HOLS & $23.3^{\mathrm{a}}$ & $14.9^{\mathrm{b}}$ & $22.8^{\mathrm{a}}$ & 1.3 & 0.38 & 0.001 & 0.49 \\
\hline & MONT & 23.9 & 14.5 & 25.3 & 1.1 & & & \\
\hline \multirow[t]{2}{*}{$16: 0$} & HOLS & $35.0^{\mathrm{b}}$ & $26.6^{\mathrm{c}}$ & $35.2^{\mathrm{a}}$ & 1.1 & 0.89 & 0.001 & 0.18 \\
\hline & MONT & 33.6 & 25.8 & 37.8 & 0.9 & & & \\
\hline $18: 0$ & HOLS & $7.2^{\mathrm{b}}$ & $11.1^{\mathrm{a}}$ & $8.1^{\mathrm{b}}$ & 0.6 & 0.02 & 0.001 & 0.25 \\
\hline cis-9 18:1 & MONT & 18.7 & 31.2 & 15.1 & 1.4 & & & \\
\hline \multirow[t]{2}{*}{$\Sigma>\mathrm{C} 16^{3}$} & HOLS & $33.0^{\mathrm{b}}$ & $52.2^{\mathrm{a}}$ & $33.8^{\mathrm{b}}$ & 2.2 & 0.43 & 0.001 & 0.30 \\
\hline & MONT & 33.2 & 53.2 & 28.3 & 1.9 & & & \\
\hline \multirow[t]{2}{*}{$\Sigma$ OBCFA } & HOLS & 3.9 & 3.7 & 4.0 & 0.2 & 0.37 & 0.68 & 0.11 \\
\hline & MONT & 3.7 & 3.8 & 3.6 & 0.2 & & & \\
\hline \multirow[t]{2}{*}{$\Sigma$ OBCFA $<\mathrm{C} 16^{4}$} & HOLS & $2.2^{\mathrm{b}}$ & $1.8^{\mathrm{c}}$ & $2.5^{\mathrm{a}}$ & 0.2 & 0.64 & 0.001 & 0.81 \\
\hline & MONT & 2.1 & 1.8 & 2.4 & 0.1 & & & \\
\hline
\end{tabular}

\footnotetext{
${ }^{\mathrm{a}-\mathrm{c}}$ Period means (main period effects pooled across both breeds) not sharing a common superscript differ $(P \leq 0.05)$.

${ }^{1}$ Intake was limited to meet $50 \%$ of $\mathrm{NE}_{\mathrm{L}}$ requirements during restriction period (RES, d 1 to 6 ). Cows were allowed ad libitum intake during control period (CON, d -3 to -1 ) and after restriction (W1, d 7 to 13).

${ }^{2}$ Sum of FA with between 10 and 15 carbons.

${ }^{3}$ Sum of FA with $>16$ carbons.

${ }^{4}$ Sum of odd- and branched-chain FA (OBCFA) with $<16$ carbons.
} 
Billa et al.: MILK METABOLITES DURING UNDERNUTRITION

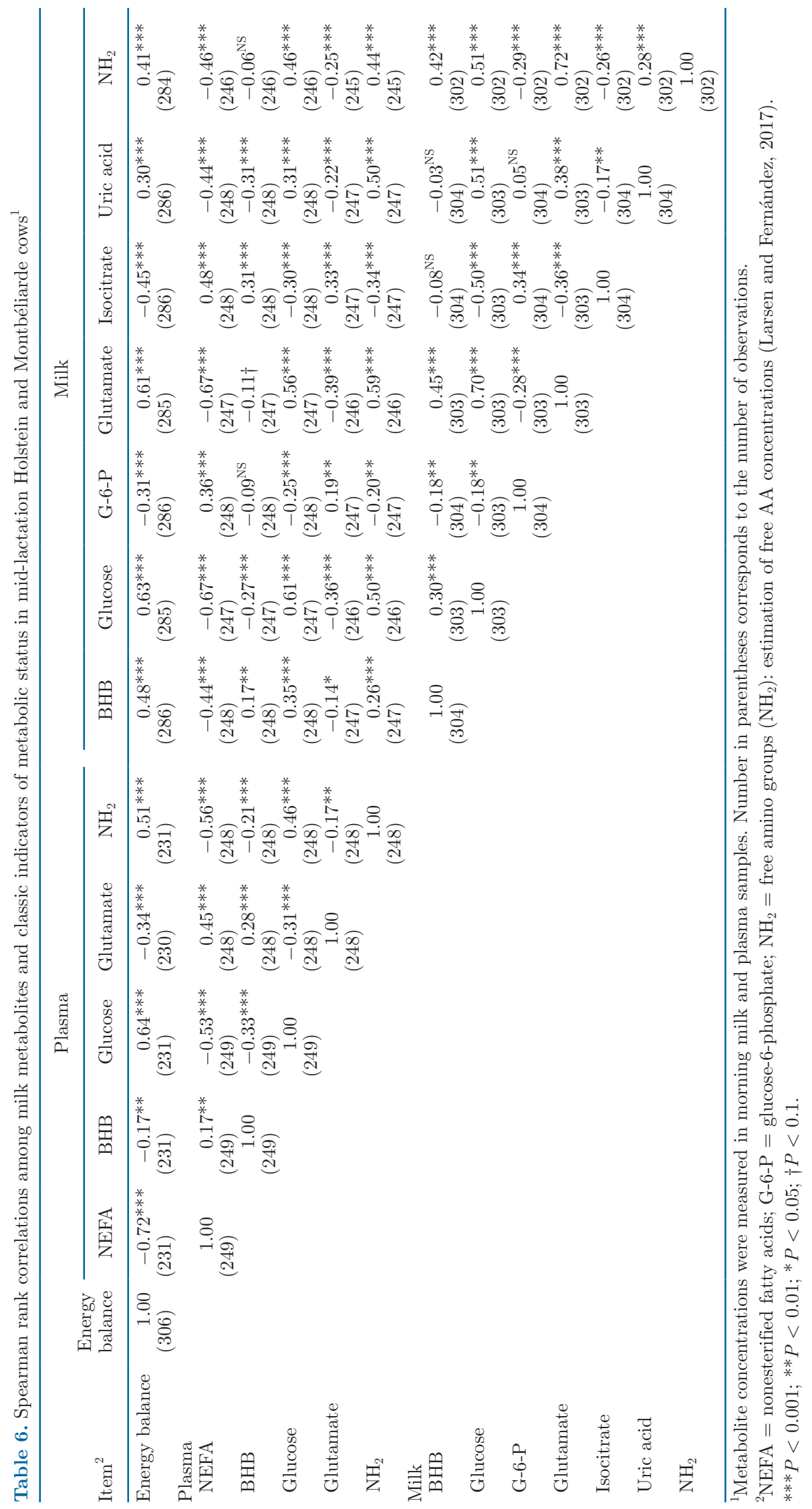


Table 7. Spearman rank correlations among milk fatty acid (FA) concentrations (composition measured in pooled p.m. and a.m. samples) and milk metabolites and classic indicators of metabolic status in mid-lactation Holstein and Montbéliarde cows ${ }^{1}$

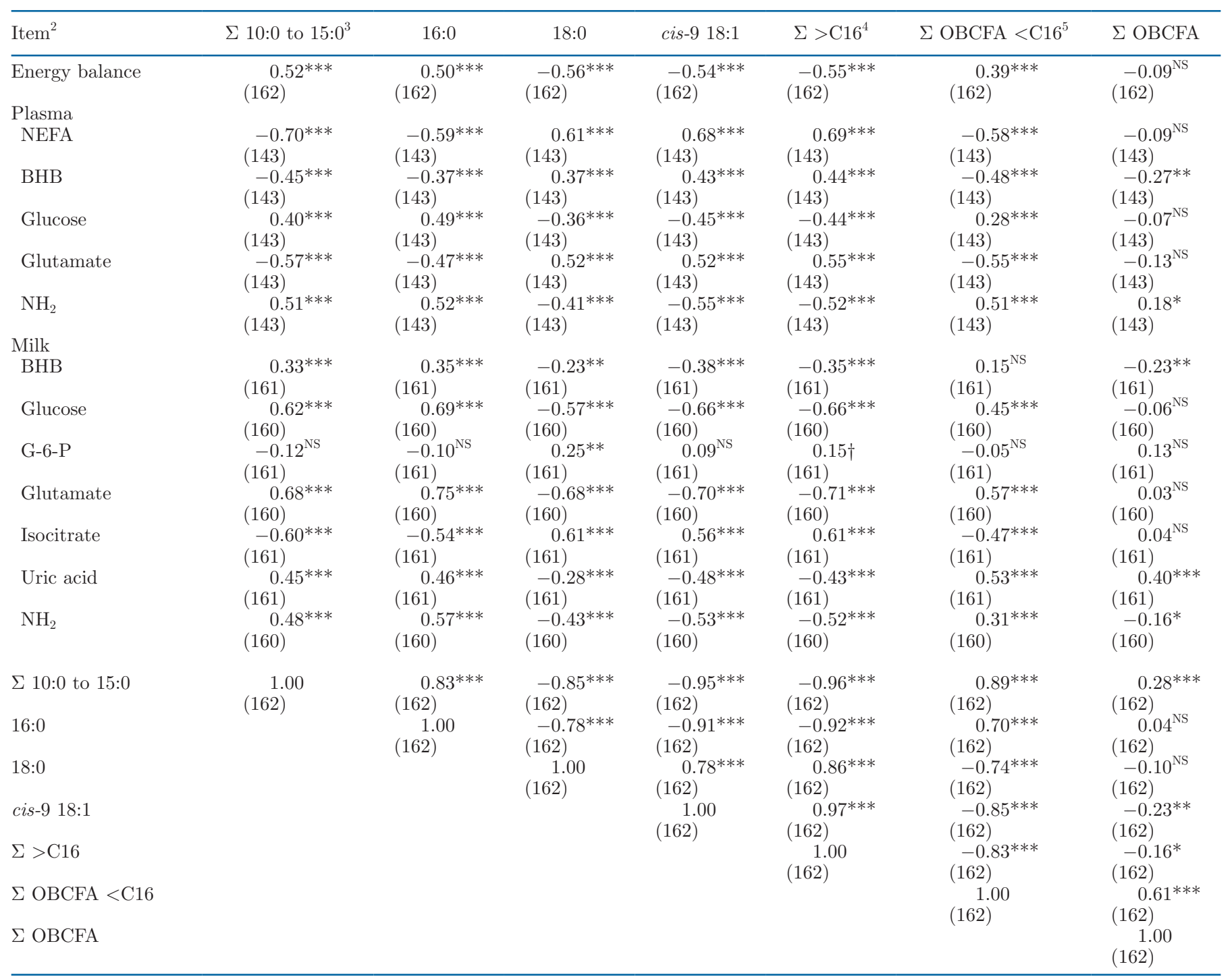

${ }^{1}$ Metabolite concentrations were measured in morning milk and plasma samples. Number in parentheses corresponds to the number of observations.

${ }^{2} \mathrm{NEFA}=$ nonesterified fatty acids; G-6-P = glucose-6-phosphate; $\mathrm{NH}_{2}=$ free amino groups $\left(\mathrm{NH}_{2}\right)$ : estimation of free AA concentrations (Larsen and Fernández, 2017).

${ }^{3}$ Sum of FA with between 10 and 15 carbons.

${ }^{4}$ Sum of FA with $>16$ carbons.

${ }^{5}$ Sum of odd- and branched-chain FA (OBCFA) with $<16$ carbons.

${ }^{* * *} P<0.001 ;{ }^{* *} P<0.01 ;{ }^{*} P<0.05 ; \dagger P<0.1$.

et al., 2013). Accordingly, FA potentially synthesized de novo in mammary gland, such as $\Sigma 10: 0$ to $15: 0$ and OBCFA $<$ C16, were positively correlated with plasma glucose and negatively correlated with plasma NEFA and BHB. Opposite correlations were observed among these plasma metabolites and $\Sigma>\mathrm{C} 16$, which are FA potentially mobilized from adipose. Moreover, milk glucose, glutamate, and isocitrate concentrations were significantly correlated with all reported milk FA and
FA classes $\left(r_{\mathrm{s}}>0.45\right.$ in absolute value), except for total OBCFA, further supporting the potential of milk glucose, glutamate, and isocitrate as biomarkers of NEB and metabolic status of dairy cows.

\section{CONCLUSIONS}

The feed restriction model induced NEB and modified plasma metabolites and milk FA concentrations in 
A

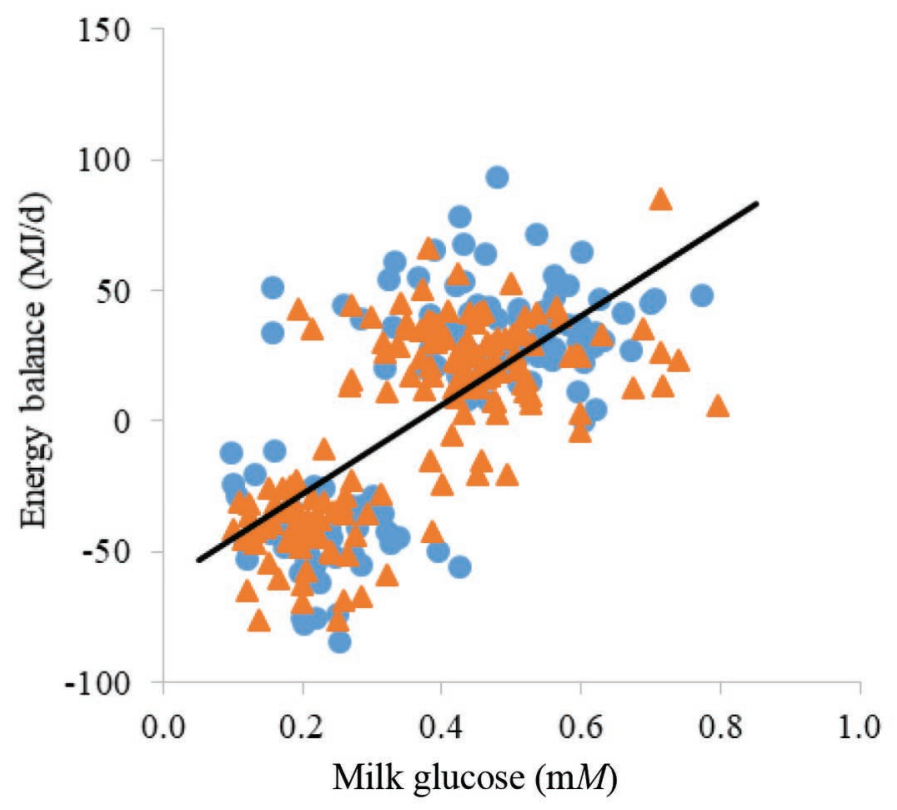

$\mathrm{C}$

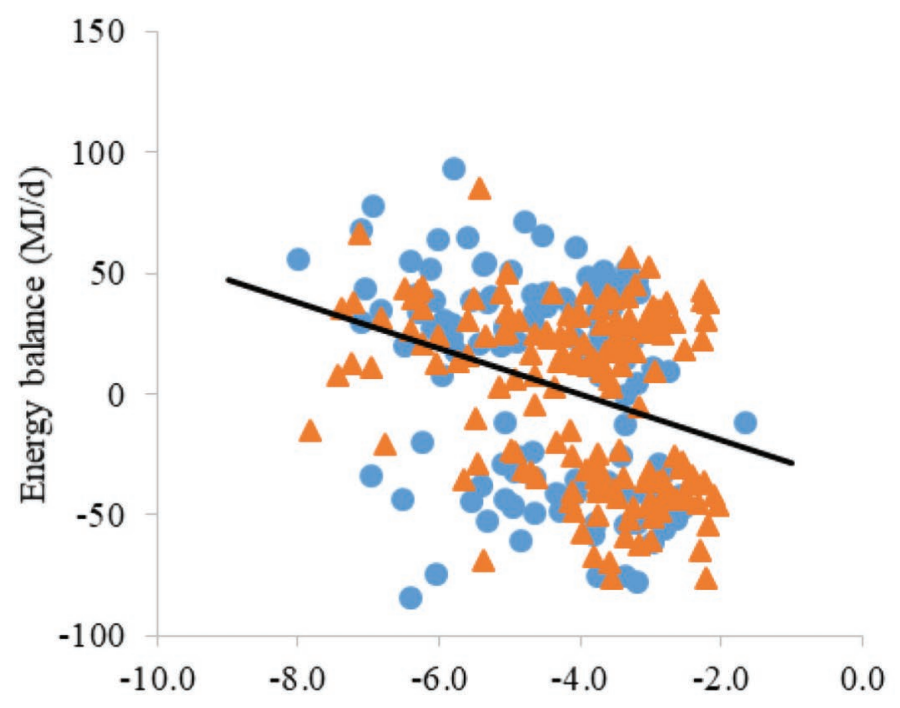

Milk glucose-6-phosphate $(\ln (\mathrm{m} M))$
B

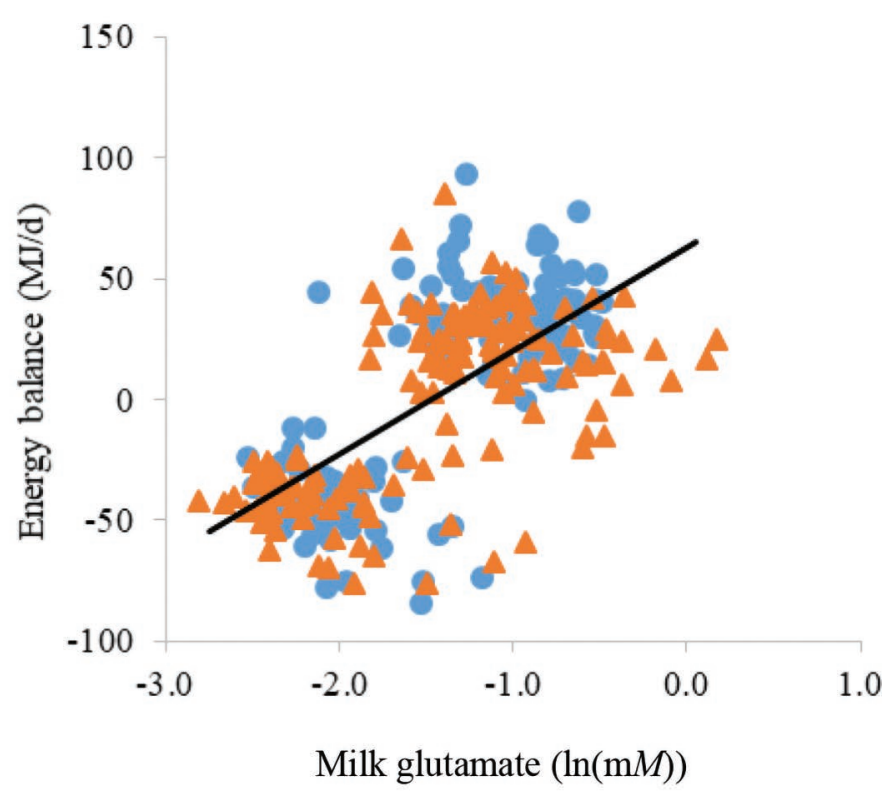

$\mathrm{D}$

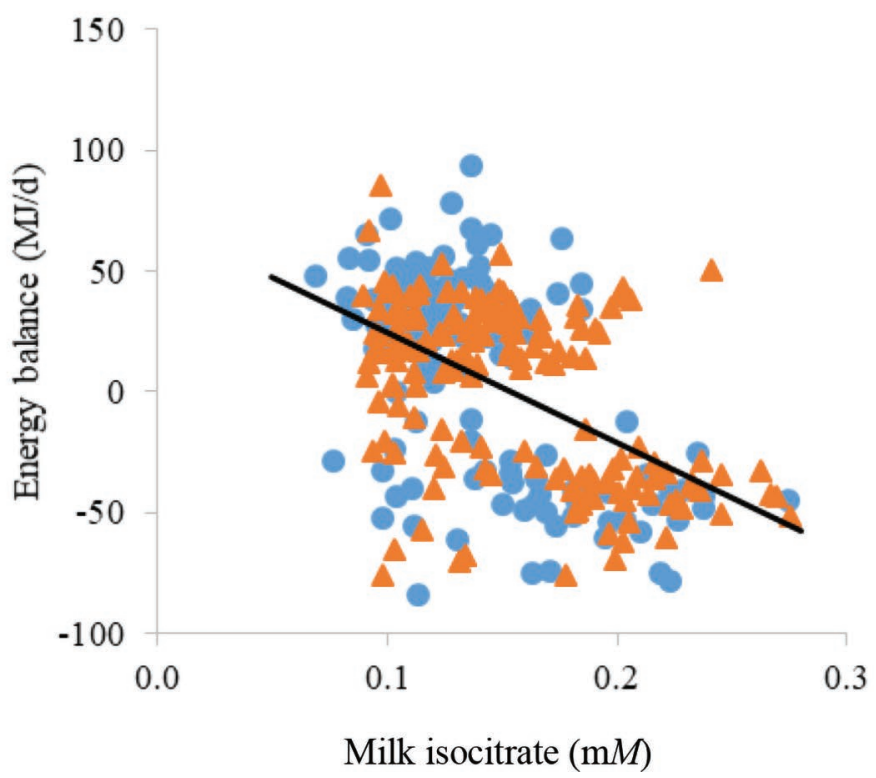

Figure 4. Relationship between energy balance and (A) milk glucose ( $\left.\mathrm{y}=171.0 \mathrm{x}-62.1, \mathrm{R}^{2}=0.49\right)$, (B) natural log of milk glutamate (y $\left.=42.7 \mathrm{x}+62.7, \mathrm{R}^{2}=0.46\right),(\mathrm{C})$ natural $\log$ of milk glucose-6-phosphate $\left(\mathrm{y}=-9.5 \mathrm{x}-37.8, \mathrm{R}^{2}=0.10\right)$, and (D) milk isocitrate $(\mathrm{y}=-458.4+$ $\left.70.7, \mathrm{R}^{2}=0.26\right)$ in mid-lactation Holstein (HOLS; $\bullet$ ) and Montbéliarde (MONT; $\left.\mathbf{\Delta}\right)$ cows $(P<0.001)$. Intake was limited to meet $50 \%$ of NE requirements during restriction period ( $\mathrm{d} 1$ to 6 ). Cows were allowed ad libitum intake during control period (d -3 to -1 ) and after restriction (d 7 to 18$)$.

mid-lactation cows as expected. The absence of marked breed differences for most variables may be explained by the short duration of the nutritional challenge $(6 \mathrm{~d})$ and lactation stage, as phenotypical differences exist between HOLS and MONT during early lactation. Milk concentrations of FA and selected metabolites were modulated by feed restriction in mid-lactation cows. Milk glucose and glutamate concentrations presented the strongest correlations with classic indicators of metabolic status and the best regressions with energy 
balance under this experimental model. Milk glucose and glutamate concentrations may constitute good noninvasive indicators of energy balance, lipomobilization, and metabolic status. Further research is warranted in early-lactation cows, because feed restriction models during established lactation lead to relatively smaller deviations of classic indicators of NEB and metabolic status compared with early lactation.

\section{ACKNOWLEDGMENTS}

The authors thank the staff at Herbipôle INRAE (UE1414, Marcenat, France) for animal care and sampling; A. Delavaud, S. Bes, D. Chadeyron, E. Tixier, and M. Tourret (INRAE, UMR1213, Saint-GenèsChampanelle, France) for sample collection and laboratory analyses; J. Clausen and C. Berthelsen (Aarhus University, Tjele, Denmark) for milk metabolite analyses. This research was partially funded by FEDER and Région Auvergne S3 project no. 23000794, and Compte d'affection Spécial au Développement Agricole et Rural (CASDAR; Paris, France) project no. 00001908 (Biomarq'lait). The authors declare no conflicts of interest.

\section{REFERENCES}

Abdelatty, A. M., M. E. Iwaniuk, M. Garcia, K. M. Moyes, B. B. Teter, P. Delmonte, A. K. G. Kadegowda, M. A. Tony, F. F. Mohamad, and R. A. Erdman. 2017. Effect of short-term feed restriction on temporal changes in milk components and mammary lipogenic gene expression in mid-lactation Holstein dairy cows. J. Dairy Sci. 100:4000-4013. https://doi.org/10.3168/jds.2016-11130.

Bell, A. W., and D. E. Bauman. 1997. Adaptations of glucose metabolism during pregnancy and lactation. J. Mammary Gland Biol. Neoplasia 2:265-278. https://doi.org/10.1023/a:1026336505343.

Billa, P. A., Y. Faulconnier, T. Ye, M. Chervet, F. Le Provost, J. A. A. Pires, and C. Leroux. 2019. Deep RNA-Seq reveals miRNome differences in mammary tissue of lactating Holstein and Montbéliarde cows. BMC Genomics 20:621. https://doi.org/10.1186/ s12864-019-5987-4.

Bjerre-Harpøth, V., N. C. Friggens, V. M. Thorup, T. Larsen, B. M. Damgaard, K. L. Ingvartsen, and K. M. Moyes. 2012. Metabolic and production profiles of dairy cows in response to decreased nutrient density to increase physiological imbalance at different stages of lactation. J. Dairy Sci. 95:2362-2380. https://doi.org/10 $.3168 /$ jds.2011-4419.

Chaiyabutr, N., A. Faulkner, and M. Peaker. 1981. Changes in the concentrations of the minor Constituents of goat's milk during starvation and on refeeding of the lactating animal and their relationship to mammary gland metabolism. Br. J. Nutr. 45:149-157. https://doi.org/10.1079/bjn19810087.

Chilliard, Y., A. Ferlay, Y. Faulconnier, M. Bonnet, J. Rouel, and F. Bocquier. 2000a. Adipose tissue metabolism and its role in adaptations to undernutrition in ruminants. Proc. Nutr. Soc. 59:127-134. https://doi.org/10.1017/s002966510000015x.

Chilliard, Y., A. Ferlay, R. M. Mansbridge, and M. Doreau. 2000b. Ruminant milk fat plasticity: nutritional control of saturated, polyunsaturated, trans and conjugated fatty acids. Ann. Zootech. 49:181-205. https://doi.org/10.1051/animres:2000117.

Contreras, G. A., K. Thelen, S. E. Schmidt, C. Strieder-Barboza, C. L. Preseault, W. Raphael, M. Kiupel, J. Caron, and A. L. Lock.
2016. Adipose tissue remodeling in late-lactation dairy cows during feed-restriction-induced negative energy balance. J. Dairy Sci. 99:10009-10021. https://doi.org/10.3168/jds.2016-11552.

Dillon, P., F. Buckley, P. O'Connor, D. Hegarty, and M. Rath. 2003. A comparison of different dairy cow breeds on a seasonal grass-based system of milk production: 1. Milk production, live weight, body condition score and DM intake. Livest. Prod. Sci. 83:21-33. https: //doi.org/10.1016/S0301-6226(03)00041-1.

Ferlay, A., B. Martin, S. Lerch, M. Gobert, P. Pradel, and Y. Chilliard. 2010. Effects of supplementation of maize silage diets with extruded linseed, vitamin $\mathrm{E}$ and plant extracts rich in polyphenols, and morning v. evening milking on milk fatty acid profiles in Holstein and Montbéliarde cows. Animal 4:627-640. https://doi.org/ 10.1017/S1751731109991224.

Ferris, C. P., P. J. Purcell, A. W. Gordon, T. Larsen, and M. Vestergaard. 2018. Performance of Holstein and Swedish-Red $\times$ Jersey $/$ Holstein crossbred dairy cows within low- and medium-concentrate grassland-based systems. J. Dairy Sci. 101:7258-7273. https: //doi.org/10.3168/jds.2017-14107.

Friggens, N. C., L. Brun-Lafleur, P. Faverdin, D. Sauvant, and O. Martin. 2013. Advances in predicting nutrient partitioning in the dairy cow: recognizing the central role of genotype and its expression through time. Animal 7(S1):89-101. https://doi.org/10.1017/ S1751731111001820.

Friggens, N. C., C. Duvaux-Ponter, M. P. Etienne, T. Mary-Huard, and P. Schmidely. 2016. Characterizing individual differences in animal responses to a nutritional challenge: Toward improved robustness measures. J. Dairy Sci. 99:2704-2718. https://doi.org/10 .3168/jds.2015-10162.

Garnsworthy, P. C., L. L. Masson, A. L. Lock, and T. T. Mottram. 2006. Variation of milk citrate with stage of lactation and de novo fatty acid synthesis in dairy cows. J. Dairy Sci. 89:1604-1612. https://doi.org/10.3168/jds.S0022-0302(06)72227-5.

Girard, C. L., N. Vanacker, V. Beaudet, M. Duplessis, and P. Lacasse. 2019. Glucose and insulin responses to an intravenous glucose tolerance test administered to feed-restricted dairy cows receiving folic acid and vitamin B12 supplements. J. Dairy Sci. 102:62266234. https://doi.org/10.3168/jds.2019-16298.

Gross, J., H. A. van Dorland, R. M. Bruckmaier, and F. J. Schwarz. 2011a. Performance and metabolic profile of dairy cows during a lactational and deliberately induced negative energy balance with subsequent realimentation. J. Dairy Sci. 94:1820-1830. https://doi .org $/ 10.3168 /$ jds.2010-3707.

Gross, J., H. A. van Dorland, R. M. Bruckmaier, and F. J. Schwarz. 2011b. Milk fatty acid profile related to energy balance in dairy cows. J. Dairy Res. 78:479-488. https://doi.org/10.1017/ S0022029911000550.

Gross, J. J., and R. M. Bruckmaier. 2019. Review: Metabolic challenges in lactating dairy cows and their assessment via established and novel indicators in milk. Animal 13(s1):s75-s81. https://doi .org/10.1017/S175173111800349X.

INRA. 2007. Alimentation des bovins, ovins et caprins: Besoins des animaux, valeurs des aliments. Editions Quae Versailles, France.

Larsen, T. 2014. Fluorometric determination of free and total isocitrate in bovine milk. J. Dairy Sci. 97:7498-7504. https://doi.org/ $10.3168 /$ jds.2014-8018.

Larsen, T. 2015. Fluorometric determination of free glucose and glucose 6-phosphate in cows' milk and other opaque matrices. Food Chem. 166:283-286. https://doi.org/10.1016/j.foodchem.2014.06 .017 .

Larsen, T., L. Alstrup, and M. R. Weisbjerg. 2016. Minor milk constituents are affected by protein concentration and forage digestibility in the feed ration. J. Dairy Res. 83:12-19. https://doi.org/ 10.1017/S0022029915000692.

Larsen, T., and C. Fernández. 2017. Enzymatic-fluorometric analyses for glutamine, glutamate and free amino groups in protein-free plasma and milk. J. Dairy Res. 84:32-35. https://doi.org/10.1017/ S0022029916000789.

Larsen, T., and K. M. Moyes. 2010. Fluorometric determination of uric acid in bovine milk. J. Dairy Res. 77:438-444. https://doi.org/10 $.1017 /$ S0022029910000580. 
Larsen, T., and K. M. Moyes. 2015. Are free glucose and glucose-6-phosphate in milk indicators of specific physiological states in the cow? Animal 9:86-93. https://doi.org/10.1017/S1751731114002043.

Larsen, T., and N. I. Nielsen. 2005. Fluorometric determination of $\beta$-hydroxybutyrate in milk and blood plasma. J. Dairy Sci 88:2004-2009. https://doi.org/10.3168/jds.S0022-0302(05)72876 -9 .

LeBlanc, S. J., K. E. Leslie, and T. F. Duffield. 2005. Metabolic predictors of displaced abomasum in dairy cattle. J. Dairy Sci. 88:159-170. https://doi.org/10.3168/jds.S0022-0302(05)72674-6.

Lerch, S., A. Ferlay, K. J. Shingfield, B. Martin, D. Pomiès, and Y. Chilliard. 2012. Rapeseed or linseed supplements in grass-based diets: Effects on milk fatty acid composition of Holstein cows over two consecutive lactations. J. Dairy Sci. 95:5221-5241. https://doi .org/10.3168/jds.2012-5337.

Lobley, G. E., S. O. Hoskin, and C. J. McNeil. 2001. Glutamine in animal science and production. J. Nutr. 131:2525S-2531S. https:/ /doi.org/10.1093/jn/131.9.2525S.

Meijer, G. A., J. Van der Meulen, J. G. M. Bakker, C. J. Van der Koelen, and A. M. Van Vuuren. 1995. Free amino acids in plasma and muscle of high yielding dairy cows in early lactation. J. Dairy Sci. 78:1131-1141. https://doi.org/10.3168/jds.S0022-0302(95)76730 -3 .

Miettinen, H., and P. Huhtanen. 1996. Effects of the ratio of ruminal propionate to butyrate on milk yield and blood metabolites in dairy cows. J. Dairy Sci. 79:851-861. https://doi.org/10.3168/jds S0022-0302(96)76434-2.

Moyes, K. M., J. K. Drackley, J. L. Salak-Johnson, D. E. Morin, J. C. Hope, and J. J. Loor. 2009. Dietary-induced negative energy balance has minimal effects on innate immunity during a Streptococcus uberis mastitis challenge in dairy cows during midlactation. J. Dairy Sci. 92:4301-4316. https://doi.org/10.3168/jds.2009-2170.

Nielsen, N. I., K. L. Ingvartsen, and T. Larsen. 2003. Diurnal variation and the effect of feed restriction on plasma and milk metabolites in TMR-fed dairy cows. J. Vet. Med. A Physiol. Pathol. Clin. Med. 50:88-97. https://doi.org/10.1046/j.1439-0442.2003.00496.x.

Oetzel, G. R. 2004. Monitoring and testing dairy herds for metabolic disease. Vet. Clin. North Am. Food Anim. Pract. 20:651-674. https://doi.org/10.1016/j.cvfa.2004.06.006.

Pawłowski, K., J. A. A. Pires, Y. Faulconnier, C. Chambon, P. Germon, C. Boby, and C. Leroux. 2019. Mammary gland transcriptome and proteome modifications by nutrient restriction in early lactation Holstein cows challenged with intra-mammary lipopolysaccharide. Int. J. Mol. Sci. 20:1156. https://doi.org/10.3390/ijms20051156.

Pires, J. A. A., Y. Chilliard, C. Delavaud, J. Rouel, D. Pomiès, and F. Blanc. 2015. Physiological adaptations and ovarian cyclicity of Holstein and Montbéliarde cows under two low-input production systems. Animal 9:1986-1995. https://doi.org/10.1017/ S1751731115001317.

Pires, J. A. A., C. Delavaud, Y. Faulconnier, D. Pomiès, and Y. Chilliard. 2013. Effects of body condition score at calving on indicators of fat and protein mobilization of periparturient Holstein-Friesian cows. J. Dairy Sci. 96:6423-6439. https://doi.org/10.3168/jds.2013 $-6801$.

Pires, J. A. A., K. Pawlowski, J. Rouel, C. Delavaud, G. Foucras, P. Germon, and C. Leroux. 2019. Undernutrition modified metabolic responses to intramammary lipopolysaccharide but had limited effects on selected inflammation indicators in early-lactation cows. J. Dairy Sci. 102:5347-5360. https://doi.org/10.3168/jds.2018-15446.

Pires, J. A. A., L. F. Stumpf, I. D. Soutullo, J. B. Pescara, S. E. Stocks, and R. R. Grummer. 2016. Effects of abomasal infusion of nicotinic acid on responses to glucose and $\beta$-agonist challenges in underfed lactating cows. J. Dairy Sci. 99:2297-2307. https://doi .org/10.3168/jds.2015-10308.

Pomiès, D., B. Martin, Y. Chilliard, P. Pradel, and B. Rémond. 2007. Once-a-day milking of Holstein and Montbéliarde cows for 7 weeks in mid-lactation. Animal 1:1497-1505. https://doi.org/10.1017/ S1751731107000778.

Vlaeminck, B., C. Dufour, A. M. van Vuuren, A. R. J. Cabrita, R. J. Dewhurst, D. Demeyer, and V. Fievez. 2005. Use of odd and branched-chain fatty acids in rumen contents and milk as a potential microbial marker. J. Dairy Sci. 88:1031-1042. https://doi.org/ 10.3168/jds.S0022-0302(05)72771-5.

Vlaeminck, B., R. Gervais, M. M. Rahman, F. Gadeyne, M. Gorniak, M. Doreau, and V. Fievez. 2015. Postruminal synthesis modifies the odd- and branched-chain fatty acid profile from the duodenum to milk. J. Dairy Sci. 98:4829-4840. https://doi.org/10.3168/jds .2014-9207.

Zachut, M., G. Kra, Y. Portnik, F. Shapiro, and N. Silanikove. 2016. Milk glucose-6-phosphate dehydrogenase activity and glucose6-phosphate are associated with oxidative stress and serve as indicators of energy balance in dairy cows. RSC Advances 6:6541265417. https://doi.org/10.1039/C6RA11924G.

\section{ORCIDS}

P. A. Billa $\odot$ https://orcid.org/0000-0002-1006-4847

T. Larsen (๑ https://orcid.org/0000-0003-3058-5938

C. Leroux @ https://orcid.org/0000-0001-6835-3978

J. A. A. Pires @ https://orcid.org/0000-0002-3773-9293 